\title{
Gambaran Mikroskopik Serebelum Tikus Putih Hamil yang Terpapar Gelombang Elektromagnetik Telepon Seluler
}

\author{
Erma Mexcorry Sumbayak ${ }^{1,}$ Della Nabila², Purnamawati ${ }^{1}$ \\ ${ }^{1}$ Departemen Histopatologi Anatomi, Fakultas Kedokteran dan Ilmu Kesehatan, Universitas Kristen Krida \\ Wacana, Jakarta, Indonesia \\ ${ }^{2}$ Fakultas Kedokteran dan Ilmu Kesehatan, Universitas Kristen Krida Wacana, Jakarta, Indonesia \\ Alamat Korespondensi: erma.mexcorry@ukrida.ac.id
}

\begin{abstract}
Abstrak
Telah diketahui bahwa gelombang elektromagnetik dapat menyebabkan terjadinya stres oksidatif di tingkat seluler. Tubuh memiliki antioksidan sebagai mekanisme pertahanan terhadap stres oksidatif, namun pada peningkatan oksidan seperti penggunaan telepon seluler yang berlebihan pada kehamilan, maka keseimbangan oksidan dan antioksidan dapat terganggu sehingga terjadi stres okdidatif yang dapat merusak jaringan biologis mahluk hidup. Penelitian bertujuan untuk mengetahui dampak radiasi elektromagnetik yang dipancarkan teleppon genggam terhadap perubahan struktur mikroskopik serebelum tikus putih pada masa kehamilan. Metode penelitian menggunakan metode rancangan post test only control group design dengan teknik simple random sampling. Perlakuan radiasi dilakukan selama 40 hari (21 hari sebelum kehamilan dan 19 hari selama kehamilan). Organ otak (serebelum) selanjutnya dibuat sediaan dengan pewarnaan HE dan dianalisis gambaran mikroskopiknya dengan fokus kepada sel-sel purkinjenya. Hasil penelitian menunjukkan terjadinya perubahan gambaran mikroskopik sel purkinje berupa pembengkakan sel dan karioreksis pada inti sel, sedangkan jumlah sel purkinje menunjukkan penurunan pada kelompok yang mengalami perlakuan. Jumlah rata-rata penurunan tidak signifikan secara statistik yang dapat disebabkan oleh adanya adaptasi berupa proliferasi sel purkinje dan belum dipisahkannya sel normal dengan sel yang cedera saat penghitungan jumlah sel. Masih dibutuhkan penelitian selanjutnya untuk memahami mekanisme adaptasi sel otak terhadap jejas radiasi gelombang elektomagnetik pada kehamilan.
\end{abstract}

Kata Kunci : gelombang elektromagnetik, sel purkinje, serebelum

\section{Microscopic Structure of White Rat Cerebellum Due to Exposure of Cellular Phone Electromagnetic Waves During Pregnancy}

\begin{abstract}
It is well known that electromagnetic waves cause oxidative stress at the cellular levet. The body has antioxidants as a defense mechanism against oxidative stress, but when oxidants increase, such as excessive cell phone use and pregnancy, the balance of oxidants and antioxidants can be disrupted, resulting in oxidative stress that damages the biological tissues of living things. This study aims to determine the impact of electromagnetic radiation emitted by cell phones on changes in the microscopic structure of the cerebellum of white rats during pregnancy. The research method used is a post test only control group design with a simple random sampling technique. Radiation treatment was carried out for 40 days (21 days before pregnancy and 19 days during pregnancy). The brain organ (cerebellum) was then made slides with HE staining and analyzed for microscopic images with a focus on the purkinje cells. The results showed that there was a change in the microscopic picture of purkinje cells in the form of cell swelling and karyorrhexis in the cell nucleus, while the number of purkinje cells showed a decrease in the treated group. The average decrease was not statistically significant which could be due to adaptations in the form of proliferation of Purkinje cells and the non-separation of normal cells from injured cells when counting the number of cells. Further research is still needed to understand the mechanism of adaptation of brain cells to electromagnetic wave radiation injury in pregnancy.
\end{abstract}

Keywords: electromagnetic wave, cerebellum, purkinje cell 


\section{Pendahuluan}

Telepon seluler atau yang biasa disebut ponsel merupakan perangkat elektronik yang memancarkan sinyal menggunakan energi elektromagnetik dalam bentuk radiasi gelombang mikro. ${ }^{1}$ Pengguna ponsel terus meningkat setiap tahunnya. Menurut data KOMINFO (Kementerian Komunikasi dan Informatika) tahun 2018, sekitar 100 juta penduduk di Indonesia merupakan pengguna aktif ponsel, dan semakin bertambah setiap harinya. $^{2}$

Ponsel yang biasa dipakai sehari-hari masuk ke dalam kategori radiasi radiofrekuensi yaitu pada kisaran 900 sampai $1.800 \mathrm{MHz}$. Radiasi yang dapat ditimbulkan oleh ponsel ada yang bersifat langsung (dari suhu ponsel sendiri) dan tidak langsung (melalui pancaran gelombang elektromagnetik). Radiasi gelombang elektromagnetik yang dipancarkan oleh ponsel pada dasarnya kecil, namun karena interaksi penggunaan yang tinggi dan banyaknya jumlah ponsel aktif yang digunakan atau berada di sekitar pengguna, maka hal ini memungkinkan terjadinya dampak radiasi yang berpengaruh pada kesehatan, terutama pada bagian otak kecil. ${ }^{3}$

Kuatnya pancaran gelombang elektromagnetik dan letak ponsel yang menempel di kepala dapat mengubah sel-sel otak hingga berkembang abnormal sehingga berpotensi menjadi sel ganas. Tidak hanya itu, pemanasan jaringan akibat paparan radiasi elektromagnetik juga dapat merubah sel menjadi abnormal, terutama di bagian yang terkena dampak pemanasan langsung, yaitu bagian kepala. Pada serebelum (otak kecil), efek radiasi ini juga dapat memengaruhi pola migrasi sel purkinje dan mikroneuron lain. Sebagian besar neuron terkondensasi, dan di beberapa tempat margin sel neuron yang rusak tidak dapat ditentukan. Jumlah sel purkinje jelas menurun setelah terpapar radiasi. Jadi, efeknya sangat berbahaya jika sering digunakan, karena menurunnya jumlah sel purkinje mengindikasikan perubahan patologis yaitu gangguan neurodegeneratif khususnya yang berhubungan dengan terganggunya fungsi serebelum. ${ }^{4-6}$

Serebelum adalah pusat tubuh dalam mengontrol kualitas gerakan. Serebelum juga mengontrol banyak fungsi otomatis otak, seperti, mengatur sikap atau posisi tubuh, mengontrol keseimbangan, koordinasi otot dan gerakan tubuh. Selain itu, serebelum berfungsi menyimpan dan melaksanakan serangkaian gerakan otomatis yang dipelajari seperti gerakan mengunci pintu, gerakan saat menulis, dan sebagainya. Banyak penelitian telah dilakukan di berbagai negara tentang pengaruh radiasi elektromagnetik ponsel terhadap otak manusia. Paparan radiasi dapat memengaruhi gangguan fungsi serebelum, seperti gangguan keseimbangan dan koordinasi. ${ }^{7}$

Lapisan tengah korteks serebelum disusun oleh sel-sel purkinje yang merupakan neuron inhibitor. Sel purkinje melepaskan neurotransmitter GABA (gamma-aminobutyric acid) yang dapat menurunkan impuls saraf sehingga menghambat aktivitas neuron-neuron di luar korteks serebelum. Dengan cara ini, maka sel purkinje berperan dalam mengatur serta mengkoordinasikan gerakan motorik. ${ }^{8}$ Penelitian sebelumnya menunjukkan, disfungsi atau kurangnya sel purkinje khususnya pada masa awal kehidupan berkaitan dengan gangguan motorik berupa stimulasi berlebihan pada fungsi motorik yang menyebabkan sulitnya mengatur perilaku dan mengakibatkan gangguan sosial yang dikenal dengan autism spectrum disorder (ASD). ${ }^{9}$

Beberapa penelitian membuktikan bahwa perempuan lebih banyak menggunakan ponsel untuk bicara dibanding laki-laki. ${ }^{10}$ Pada perempuan hamil juga jauh lebih rentan terhadap radiasi ponsel daripada orang tidak hamil. Potensi efek radiasi lebih cepat dan lebih tinggi pada kehamilan dibandingkan tidak hamil, meskipun bila pemakaian ponsel lebih jarang dilakukan. Kehamilan lebih rentan terkena radiasi dikarenakan adaptasi tubuh dapat mudah terganggu. Adaptasi yang dimaksud adalah seperti adaptasi untuk mencegah kerusakan sel, khususnya pada otak akibat stress oksidatif. Saat tubuh diberi paparan radiasi terus menerus, sel-sel akan menjadi rusak yang diperkirakan disebabkan oleh stres oksidatif. ${ }^{11-13}$

Berdasarkan latar belakang tersebut, penelitian bertujuan untuk mengetahui apakah ada perubahan struktur mikroskopik serebelum dan jumlah sel purkinje tikus putih yang dipaparkan/diradiasi gelombang elektromagnetik sebelum dan selama kehamilan.

\section{Metodologi}

Penelitian dilakukan di Laboratorium Hewan dan Laboratorium Histologi Fakultas Kedokteran dan Ilmu Kesehatan Universtias Kristen Krida Wacana (Ukrida) Jakarta. Jenis penelitian merupakan penelitian eksperimental murni. Penelitian ini menggunakan Post test only control group design dengan teknik simple random sampling. Populasi penelitian adalah tikus betina, 
umur 2-3 bulan, berat badan $\pm 200 \mathrm{~g}$, sehat, tidak ada kelainan morfologi, dan dipelihara di laboratorium hewan Fakultas Kedokteran dan Ilmu Kesehatan Ukrida. Sampel pada penelitian ini adalah tikus betina. Besar sampel dihitung dengan metode rancangan acak lengkap dan menggunakan rumus Frederer. ${ }^{14}$

Rumus yang digunakan : $(\mathrm{t}-1)(\mathrm{n}-1) \geq 15$

Hewan coba yang digunakan pada penelitian ini adalah tikus betina (Rattus norvegicus) galur Sprague Dawley yang berjumlah 24 ekor (tiap kelompok terdiri dari 6 ekor tikus), diperoleh dari Fakultas Peternakan IPB Bogor.

Pengelompokan dilakukan secara random menjadi empat kelompok, setelah masa adaptasi. Tikus diberikan perlakuan menggunakan ponsel mode panggilan aktif tanpa suara sesuai dengan masing-masing perlakuan (kontrol atau tanpa paparan, 90 menit paparan dengan 1 ponsel atau HP, 90 menit paparan dengan $2 \mathrm{HP}, 90$ menit paparan dengan $4 \mathrm{HP}$ ) yang sudah ditentukan selama 40 hari (21 hari sebelum kehamilan dan 19 hari selama kehamilan). Perlakuan dilakukan secara konsisten menggunakan 7 ponsel yang secara resmi dijual di Indonesia dan dipergunakan dalam kehidupan sehari-hari.

Pengawinan dilakukan dengan cara seekor tikus jantan dimasukkan ke kandang yang berisi 3 ekor tikus betina virgin sekitar pukul 15.00. Jika keesokan harinya ditemukan sumbat vagina pada tikus betina, maka hari tersebut ditetapkan sebagai hari kehamilan ke- $0 .{ }^{15}$

Pada hari kehamilan ke-19 tikus perlakuan dan kontrol dikorbankan dengan cara injeksi anestesi menggunakan larutan kombinasi campuran ketamin dan xylazine dosis lethal (dengan dosis \pm $2-3 \mathrm{x}>$ dosis anestesi). Campuran ketamin 100 $\mathrm{mg} / \mathrm{KgBB}$ dan Xylazine $10 \mathrm{mg} / \mathrm{kgBB}$ disuntikkan secara intraperitoneal. ${ }^{16-18}$ Selanjutnya otak tikus diambil dan dibuat sediaan/slide mikroskopik dengan pewarnaan HE. Penggunaan tikus hamil dikaitkan dengan resiko stres oksidatif akibat radiasi elektromagnetik telepon seluler pada perempuan, hal ini dikarenakan kondisi hamil sendiri menyebabkan terjadinya stress oksidaif internal sehingga kehamilan menyebabkan lebih tingginya kerentanan terhadap oksidan dibanding tidak hamil. ${ }^{10,13}$

Pengamatan slide mikroskopik dilakukan dengan mikroskop Olympus model $\mathrm{CH} 20$, kemudian dilakukan pengambilan gambar dengan bantuan Optilab software (mengganti lensa okuler dengan kamera khusus dan menghubungkan ke laptop). Setiap slide/preparat mikroskopik otak difoto dengan perbesaran 10x10, untuk penghitungan sel purkinje dengan perbesaran 10x40. Pengukuran dilakukan dengan bantuan aplikasi Imageview. ${ }^{19}$ Data hasil penelitian diolah secara statistik melalui uji parametrik One Way Anova dan dilanjutkan dengan uji Post-Hoc.

Penelitian yang telah dilakukan merupakan bagian dari penelitian payung dan sudah mendapatkan persetujuan etik dari komisi etik FKIK UKRIDA dengan nomor 845/SLKEIM/UKKW/FKIK/KE/II/2020.

\section{Hasil}

Penelitian bertujuan untuk menganalisis gambaran mikroskopis serebelum akibat paparan radiasi gelombang elektromagnetik telepon seluler terhadap tikus betina sebelum dan selama kehamilan. Disamping itu, dilakukan juga penghitungan jumlah sel purkinje untuk melihat efek radiasi gelombang elektromagnetik terhadap proliferasi sel purkinje. Pengambilan data dilakukan dengan pemeriksaan slide mikroskopik serebelum untuk menghitung jumlah sel purkinje pada lapisan ganglioner serebelum setiap kelompok percobaan dan juga melihat perubahan besaran nukleus pada sel purkinje di tiap kelompok percobaan.

Pengamatan pada gambaran mikroskopik (Gambar 1) serebelum tikus (Rattus norvegicus) kelompok kontrol (K) yang tidak diberikan perlakuan radiasi gelombang elektromagnetik menunjukkan terdapat lapisan sel purkinje yang tersusun dalam satu baris sel purkinje pada pertautan antara lapisan molekular dan lapisan granular yang jelas dengan bentuk yang besar berbentuk multipolar beserta nukleus di dalamnya, serta tampak terlihat sel-sel granul yang padat pada lapisan granular.

Pengamatan pada gambaran mikroskopik serebelum tikus (Rattus norvegicus) kelompok perlakuan $1\left(\mathrm{P}_{1}\right)$ yang diberikan pajanan radiasi gelombang elektromagnetik menggunakan $1 \mathrm{HP}$ terhadap jumlah sel purkinje menunjukkan bahwa terdapat penurunan jumlah yang terlihat dari mulai berkurangnya kerapatan antar sel purkinje dibandingkan dengan kelompok kontrol.

Pengamatan pada gambaran mikroskopik serebelum tikus (Rattus norvegicus) kelompok perlakuan $2\left(\mathrm{P}_{2}\right)$ yang diberikan pajanan radiasi gelombang elektromagnetik menggunakan 2 HP terhadap jumlah sel purkinje menunjukkan bahwa terlihat penurunan kerapatan jumlah sel purkinje dibandingkan kontrol, namun penurunan jumlah sel purkinjenya tidak sebanyak pada kelompok P1. 
Selain itu, nampak adanya area dimana sel-sel purkinje merapat satu sama lain yang menandakan terjadinya peningkatan proliferasi.

Pengamatan selanjutnya pada gambaran mikroskopik serebelum tikus (Rattus norvegicus) pada kelompok perlakuan $3\left(\mathrm{P}_{3}\right)$ yang diberikan pajanan radiasi gelombang elektromagnetik menggunakan 4 HP terhadap jumlah sel purkinje menunjukkan penurunan hebat pada jumlah sel purkinje dibandingkan kontrol, perlakuan 1 HP dan
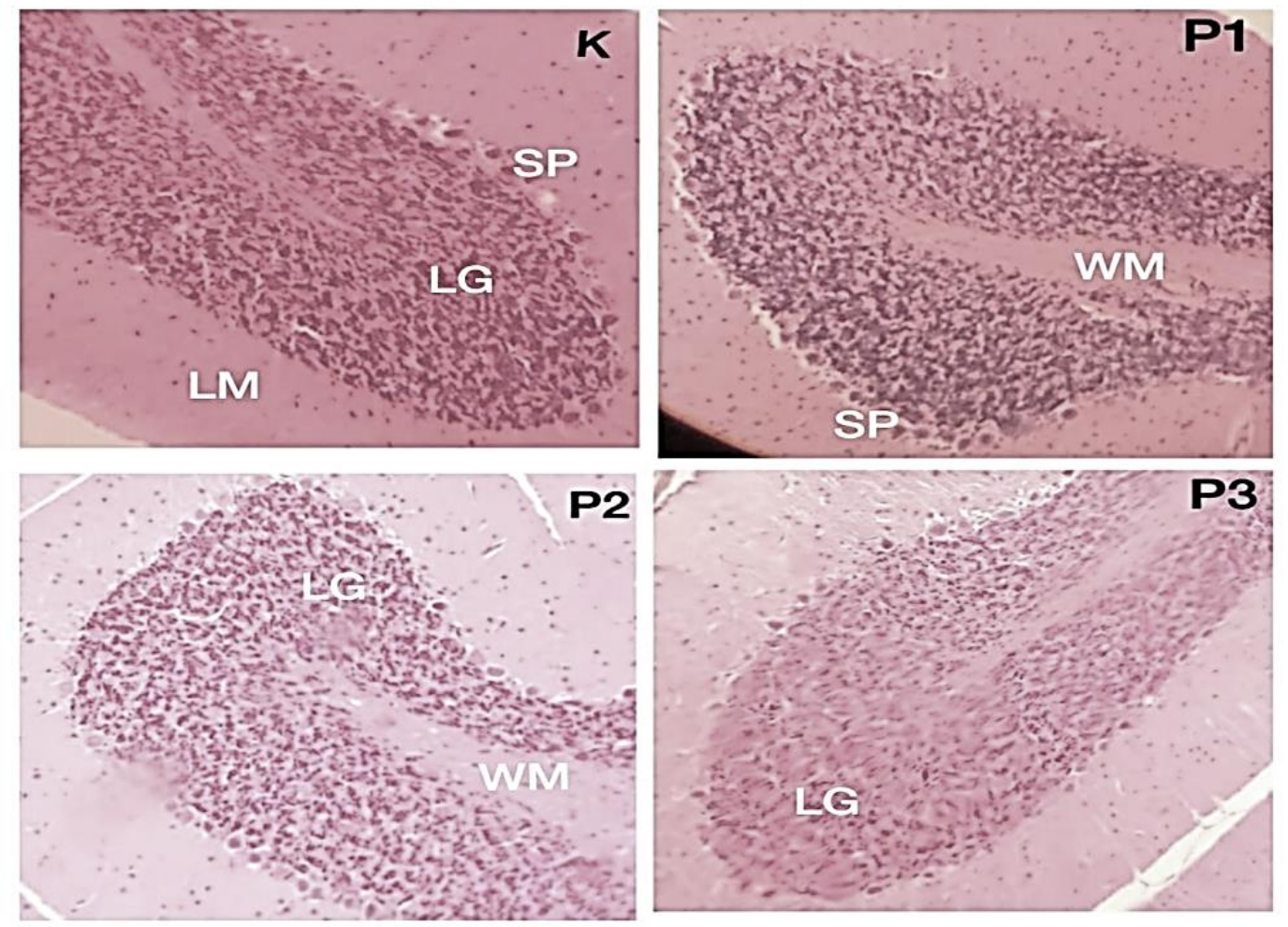

Gambar 1. Penampang Melintang Serebelum Tikus Putih (Rattus norvegicus) yang Diberikan Paparan Radiasi Gelombang Elektromagnetik HP (10x10, HE, ImageView), terlihat jumlah sel purkinje. LM: Lapisan Molekular, LG: Lapisan Granular, SP: sel Purkinye, WM: White Matter

Selanjutnya dilakukan penghitungan jumlah sel purkinje yang didapat dengan cara membandingkan jumlah sel purkinje dalam setiap kelompok percobaan yang masing-masing kelompok diambil sebanyak 3 lapang pandang serebelum (dalam 1 slide mikroskopik terdapat 2 organ serebelum), setelah itu dihitung secara manual menggunakan counter counting sebanyak
2 HP. Penurunan jumlah sel nampak pada kerapatan sel purkinje yang berkurang menunjukkan kemungkinan telah terjadinya apoptosis disamping nampak perubahan gambaran morfologis lapisan purkinje yang nampak tidak tersusun teratur dengan sitoplasma yang tampak memudar. Disamping itu perubahan juga nampak pada lapisan granular akibat kepadatan sel granular yang menurun sehingga lapisan ini nampak lebih tipis (Gambar 1). 


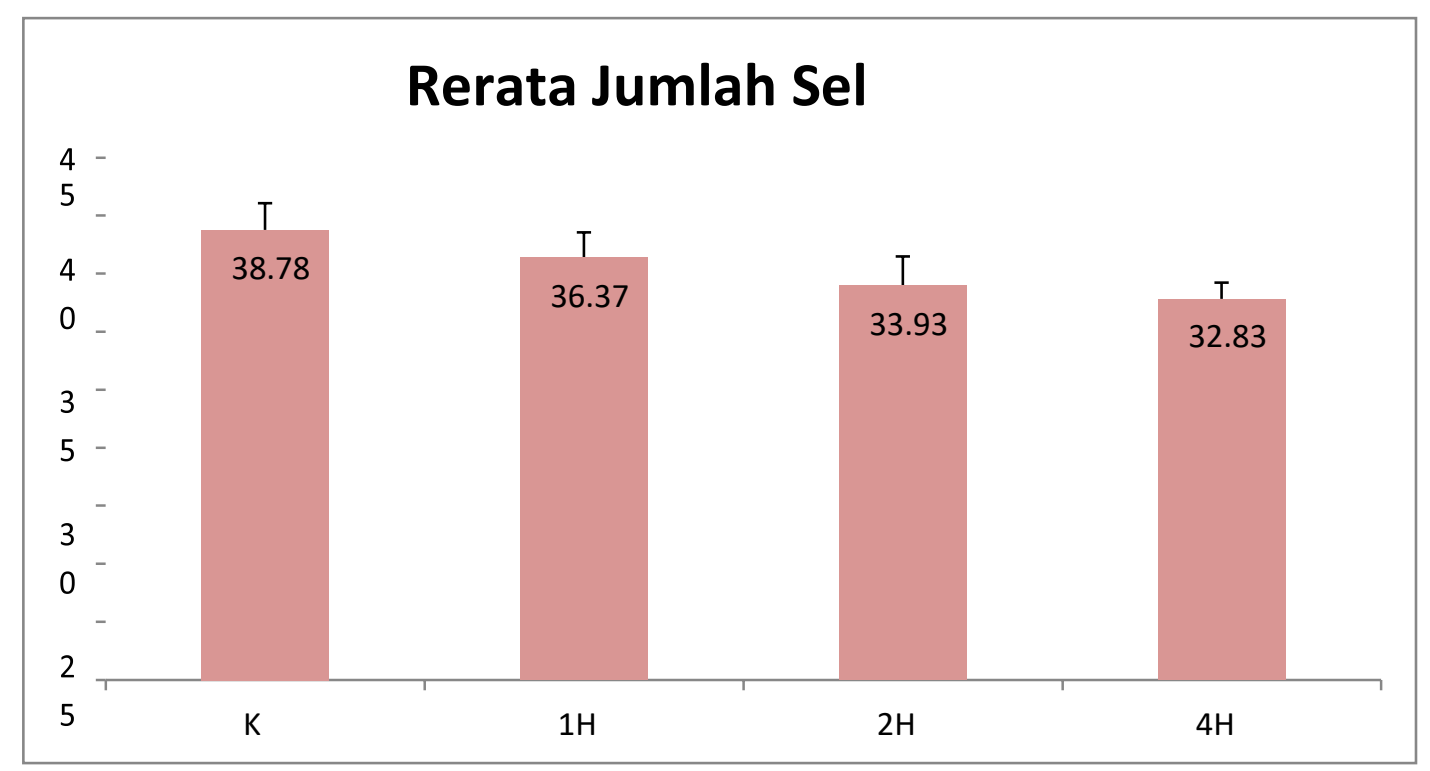

Gambar 2. Diagram Nilai Rerata Jumlah Sel Purkinje. Sumbu Y menunjukkan rerata jumlah sel purkinje, sedangkan sumbu X menunjukkan kelompok hewan coba. Kelompok kontrol (KN), serta kelompok perlakuan radiasi $1 \mathrm{HP}, 2 \mathrm{HP}$ dan $4 \mathrm{HP}$.

Pada diagram di atas (Gambar 2) terlihat bahwa rata-rata jumlah sel purkinje pada hewan coba tikus yang mendapatkan perlakuan mengalami penurunan. Hasil ini menunjukkan bahwa radiasi gelombang elektromagnetik menyebabkan turunnya rata-rata jumlah sel purkinje dibandingkan kontrol (baik pada perlakuan menggunakan 1, 2 maupun $4 \mathrm{HP}$ ).

Pada data hasil penghitungan jumlah sel purkinje kemudian dilakukan pengujian statistik menggunakan uji one way Anova yang didahului dengan uji homogenitas dengan signifikansi ditetapkan pada $\mathrm{p}<0,05$. Hasil uji homogenitas didapatkan nilai Lavene statistic dengan signifikansi sebesar 0,936 (1 HP), 0,658 (2HP), dan 0,379 (4HP), sehingga dari nilai tersebut dapat disimpulkan bahwa varian ketiga kelompok perlakuan adalah homogen. Selanjutnya dari uji one way Anova, didapatkan nilai $\mathrm{p}=0,517$ atau ( $>0,05$ ), sehingga dapat dinyatakan bahwa tidak terdapat perbedaan rata-rata yang signifikan secara uji statistik antara kelompok tikus kontrol dengan yang diberi perlakuan dengan menggunakan $1 \mathrm{HP}$, $2 \mathrm{HP}$, dan 4 HP seperti yang nampak pada grafik Box-Plot di bawah ini (Gambar 3).

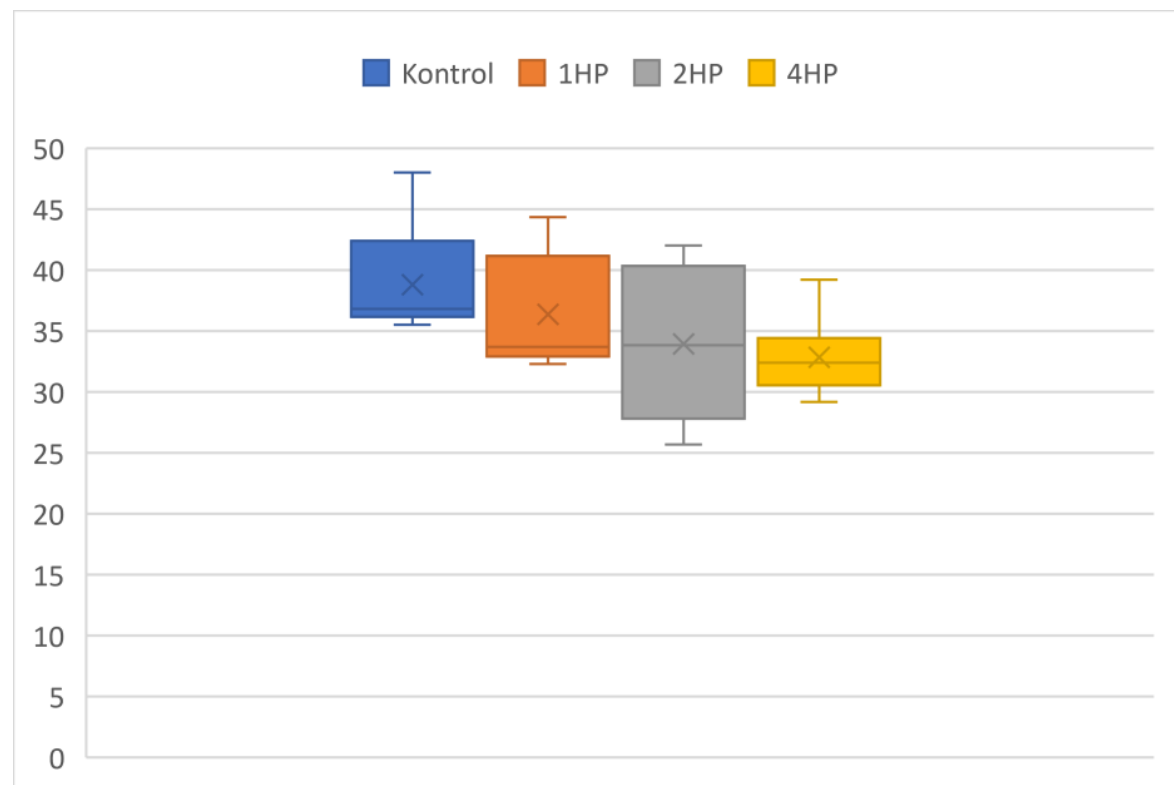

Gambar 3. Diagram Box-Plot Rerata Jumlah Sel Purkinje. Sumbu Y menunjukkan rerata jumlah sel Purkinje. Sebaran data terbesar terlihat pada box radiasi 2HP sedangkan sebaran data terkecil nampak di box radiasi $4 \mathrm{HP}$. 
Selanjutnya pada gambaran mikroskopik serebelum dengan perbesaran 40x10 pada kelompok kontrol $(\mathrm{K})$, kelompok radiasi $1 \mathrm{HP}\left(\mathrm{P}_{1}\right)$, radiasi $2 \mathrm{HP}\left(\mathrm{P}_{2}\right)$, dan radiasi $4 \mathrm{HP}\left(\mathrm{P}_{3}\right)$ dapat terlihat perbedaan dari besarnya inti sel purkinje pada masing-masing kelompok perlakuan (Gambar 4).
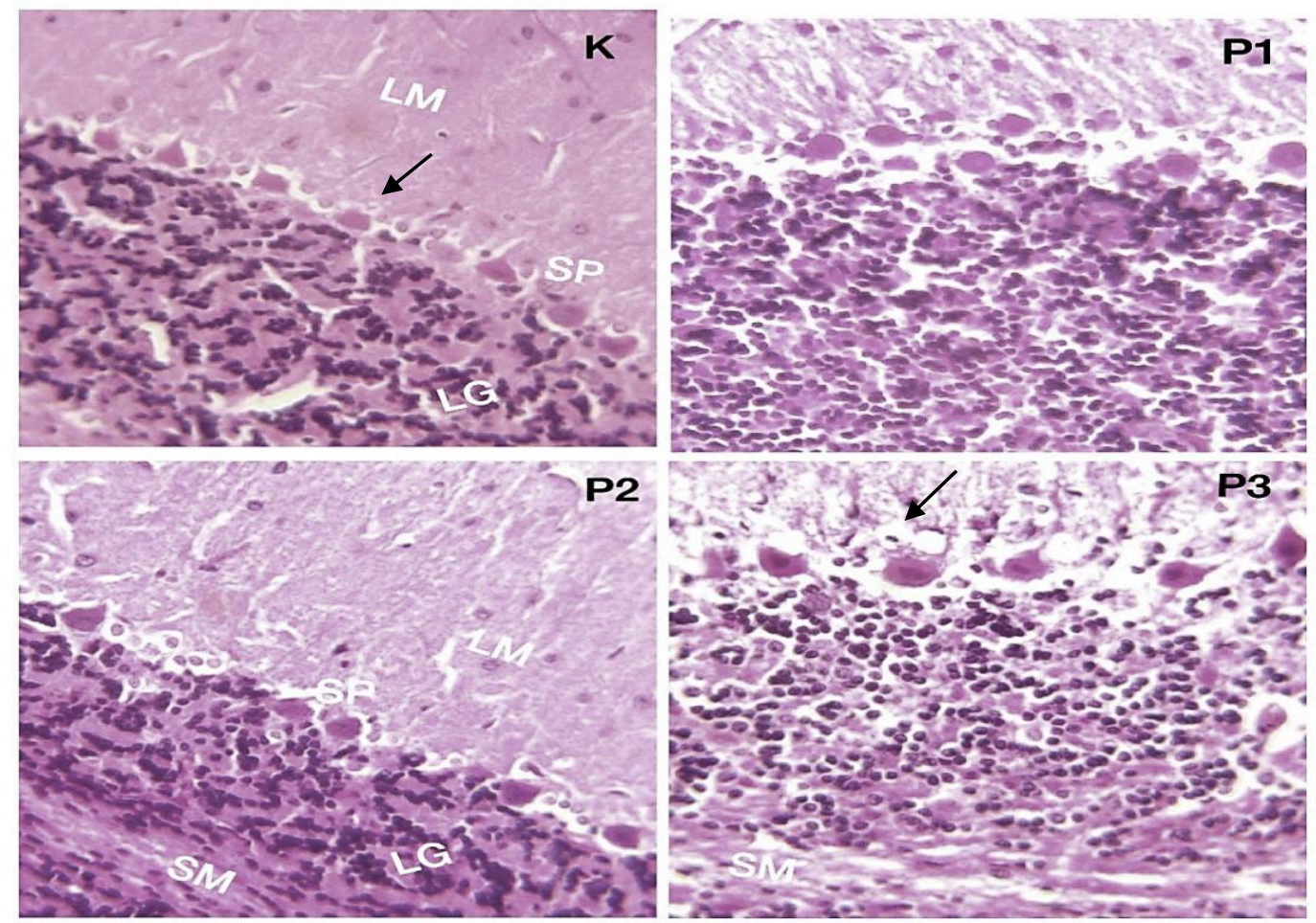

Gambar 4. Penampang Melintang Serebelum (40x10, HE, Imageview), Terlihat Inti Sel Purkinje. LM: Lapisan Molekular, LG: Lapisan Granular, SP: Sel Purkinye, SM: Sel Molekular

Dari Gambar 4 hasil pengamatan mikroskop perbesaran 40x10, terdapat perbedaan ukuran besar inti sel purkinje pada kelompok yang terpapar radiasi gelombang elektromagnetik ponsel dari pada kelompok kontrol. Pengamatan pada kelompok kontrol terlihat inti sel yang lebih kecil dan jelas pada setiap sel purkinje dengan perbandingan sekitar 1:10 dari badan sel. Pada kelompok $\mathrm{P}_{1}$, sebagian besar inti sel masih tampak, sel purkinje mulai terlihat sedikit besar dibandingkan dengan yang kelompok kontrol, dan mulai terdapat kongesti (pembendungan darah) di lapisan sekitar sel purkinje. Semakin meningkatnya jumlah ponsel untuk radiasi, maka dapat terlihat pula semakin membesarnya sel purkinje dengan inti sel yang karioreksis.

\section{Pembahasan}

Serebelum merupakan pusat keseimbangan. Salah satu lapisan serebelum yang mempunyai peran penting adalah lapisan tengah dari korteks serebelum yang disusun oleh sel-sel purkinje. Sel purkinje merupakan output dari korteks serebelum, satu-satunya neuron serebelum yang mempunyai fungsi dapat menstrasmisikan impuls eferen dari korteks serebelum. Sebagai neuron inhibitor, sel purkinje memiliki fungsi menghaluskan gerakan motorik pada alur gerak sistem ektstrapiramidal. Contoh, seperti gerakan membalikkan badan, menolehkan kepala, dan gerakan involunter lainnya. Jadi, untuk meningkatkan kualitas gerakan, perlu stimulasi dari sel purkinje dalam gerakan volunter pada fungsi motorik, menjaga keseimbangan peran neurotransmitter dalam sistem kerja di sel purkinje dan menghindari cedera sel Purkinje. ${ }^{10,20}$

Dari hasil penelitian dapat dilihat bahwa terjadi penurunan jumlah sel purkinje dari jumlah kelompok kontrol seiring dengan bertambah banyaknya ponsel yang meradiasi menurut hasil rata-rata yang di dapat. Sel purkinje yang terlihat terjadi penurunan drastis adalah kelompok perlakuan radiasi $4 \mathrm{HP}$. Namun, menurut hasil uji statistik yang dilakukan, tidak memiliki pengaruh yang bermakna terhadap jumlah sel purkinje, dan juga tampak terlihat dari masing-masing kelompok perlakuan yang menggunakan perlakuan radiasi, 
terdapat sel purkinje yang berproliferasi dan terjadi perlemakan.

Sel Purkinje yang normal pada serebelum akan berbentuk monolayer (satu lapis) dengan sel yang bentuknya normal, inti sel yang utuh, dan jumlah yang tidak terlalu rapat di antara lapisan molekuler dan lapisan granular dan dendrit tumbuh bercabang di lapisan molekuler. Jika jumlah sel purkinje mengalami penurunan, akan terjadi kerusakan sel dan penurunan fungsi. Faktor yang memicu terjadinya penurunan sel purkinje biasanya karena kondisi iskemia, karena terjadi penurunan darah ke otak (tidak adekuat), stress oksidatif, dan lainnya. ${ }^{21}$

Sel purkinje juga sangat sensitif terhadap cedera otak ringan. Pada penelitian juga didapatkan pembesaran sel purkinje jika dilihat dari pembesaran 40x10 pada kelompok perlakuan yang menggunakan radiasi dan juga inti sel di dalamnya terjadi karioreksis. Karioreksis merupakan proses kerusakan sel yang ditandai dengan pecahnya inti sel dan rusaknya kromatin dan sitoplasma berubah menjadi masa asidofil yang suram. Biasanya karena terjadinya hipoksia dan iskemik pada sel serta kerusakan jejas yang irreversible akibat stress fisiologik atau karena rangsangan patologik dari radiasi gelombang elektromagnetik ponsel. ${ }^{22}$

Secara mikroskopik, pada preparat kelompok perlakuan paparan radiasi gelombang elektromagnetik ponsel nampak terjadi proliferasi pada sel purkinje. Terjadinya proliferasi sel purkinje pada kelompok radiasi $1 \mathrm{HP}$ dan radiasi 2 HP ini dapat diakibatkan oleh mekanisme kompensasi akibat adanya jejas pada sel. Jejas berupa stres oksidatif sebagai efek dari paparan radiasi elektromagnetik pada jaringan otak yang diketahui sangat sensitif terhadap efek ROS tersebut. Dengan adanya proliferasi maka akan terjadi peningkatan jumlah sel Purkinje sebagai kompensasi dari kerusakan/hilangnya sel akibat jejas. ${ }^{23}$ Namun saat sel sudah tidak mampu lagi melakukan kompensasi, maka efek jejas pada serebelum akan nampak berupa penurunan jumlah sel purkinje, disertai pembengkakan sel yang mengarah ke degenerasi hidropik. Kondisi ini dikenal sebagai degenerasi bengkak keruh yang menyebabkan perubahan morfologi pada sel purkinje yang tampak bengkak, sehingga secara mikroskopik maupun makroskopik terjadi perubahan pada serebelum seperti tampak pada Gambar $4 .^{24,25}$

Di awal penelitian diduga bahwa kondisi kehamilan yang secara fisiologis selalu disertai dengan kondisi hipoksia ringan untuk memicu dihasilkannya faktor-faktor pertumbuhan dapat menjadi faktor yang memperberat efek radiasi elektromagnetik pada serebelum. Hal ini karena lebih mudahnya terjadi gangguan keseimbangan yang menyebabkan terjadinya stres oksidatif. ${ }^{22}$

Penelitian menunjukkan perubahan mikroskopik yang signifikan dengan terjadinya perubahan histomorfologis berupa hilangnya sel purkinje pada otak tikus yang terpapar ponsel sebelum dan selama kehamilan. Hal ini megindikasikan adanya efek negatif penggunaan telepon seluler pada serebelum, akan tetapi secara statistik perubahan yang terjadi tidak menunjukkan hasil yang signifikan. Hasil penelitian menimbulkan suatu dugaan yaitu pada saat terjadinya kehamilan yang diketahui secara fisiologis selalu disertai dengan kondisi stress oksidatif untuk kebutuhan pertumbuhan janin boleh jadi terdapat mekanisme adaptasi untuk menghindari efek buruk dari stress oksidatif khususnya pada organ vital seperti otak. Investigasi lebih lanjut tentang mekanisme molekuler adaptasi jejas stress oksidatif pada serebelum khususnya pada kehamilan sebaiknya dilakukan agar dapat memahami mekanismenya lebih jauh.

\section{Simpulan}

Berdasarkan pada hasil penelitian yang telah dilakukan, dapat disimpulkan: terjadi perubahan histomorfologis gambaran mikroskopik serebelum pada lapisan purkinje tikus putih berupa turunnya jumlah sel maupun perubahan inti serta bentuk sel akibat pajanan radiasi gelombang elektromagnetik. Terdapat mekanisme adaptasi pada radiasi elektromagnetik berupa proliferasi sel purkinje (nampak pada kelompok radiasi 2HP berupa sebaran data box-plot yang luas karena adanya area dengan kepadatan sel purkinje yang rendah dan tinggi). Hal ini menyebabkan jumlah rata-rata sel purkinje dapat bertahan sehingga tidak didapatkan perbedaan yang signifikan pada uji statistik yang membandingkan rerata jumlah sel purkinje. Ketidakbermaknaan secara statistik tidak membuktikan bahwa paparan radiasi elektromagnetik aman dalam keadaan hamil karena secara histomorfologik, nampak terjadi degenerasi pada sel purkinje yang bila dibiarkan berkelanjutan dapat menjadi irreversibel dan mengakibatkan kematian pada sel.

\section{Keterbatasan}

Dibutuhkan suatu standar penilaian yang lebih detail untuk membedakan sel normal dan sel yang 
cedera akibat jejas gelombang elektromagnetik di otak (serebelum) sehingga dapat dibedakan jumlah rerata sel yang tidak terdampak dan sel yang terdampak. Menimbang masih tingginya nilai SD (standard deviasi), maka perlu diperhitungkan penambahan jumlah sampel untuk mendapatkan hasil yang lebih akurat.

\section{Daftar Pustaka}

1. Victorya RM. Effects of handphone's electromagnetic waves exposure on seminiferoustubules. J Mayority. 2015;4(3):96-100.

2. Kementerian Komunikasi dan Informasi. Indonesia raksasa teknologi digital Asia. Diunduh dari www.kominfo.go.id pada tanggal 23 Desember 2018.

3. Nurudin. Sistem komunikasi Indonesia. Jakarta: Rajawali Pers PT. Raja Grafindo Persada; 2005.

4. Husain M, Makiyah SNN. Pengaruh pajanan gelombang telepon seluler terhadap struktur histologi limpa pada mencit. Jurnal Kedokteran Yarsi. 2012;20(3):167-73.

5. Kivrak EG, Altunkaynak BZ, Alkan I, Yurt KK, Kocaman A, Onger ME. Effects of 900 $\mathrm{MHz}$ radiation on the hippocampus and cerebellum of adult rats and attenuation of suvh effects by folic acid. J Microsc Ultrastruct. 2018;5(4):216-24.

6. Akosman MS, Gocmen-Ma N, Karabekir HS. Estimation of Purkinje cell quantification and volumetry in the cerebellum using a stereological technique. Folia Morphol. 2011;70(4):240-4.

7. Hamada AJ, Aspinder S, Ashok A. Cell phone and their impact on male fertility: fact or fiction. The Open Reproductive Science Journal. 2011;5(4):125-37.

8. Hirano T. Purkinje neurons: Development, morphology, and function. Cerebellum. 2018;17(6):699-700.

9. Sundberg M, Tochitsky I, Buchholz DE, Winden K, Kujala V, Kapur K. et al. Purkinje cells derived from TSC patients display hypoexcitability and synaptic deficits associated with reduced FMRP levels and reversed by rapamycin. Molecular Psychiatry. 2018;23(11):2167-83. https://doi.org/10.1038/s41380-018-0018-4

10. Sonmez OF, Odaci E, Bas O, Kaplan S. Purkinje cell number decrease in the adult female rat cerebellum following exposure to
$900 \mathrm{mhz}$ electromagnetic field. Brain Research 1356. 2010:95-101.

11. Krinke GJ. The handbook of experimental animals: the laboratory rat. London: Academic Press; 2000.

12. Wilantika CF. Pengaruh penggunaan smartphone terhadap kesehatan dan perilaku remaja. Diakses dari www.ejurnal.latansamashiro.ac.id pada tangal 20 Juli 2019.

13. Bak A, Roszkowski K. Oxidative stress in pregnant women. Archives of Perinatal Medicine. 2013:19(3); 150-5

14. Dahlan MS. Statistik untuk kedokteran dan kesehatan. Edisi 5. Jakarta: Salemba Medika. 2011

15. Frianto F. Inarah F, Hafrizal R. Evaluasi faktor yang mempengaruhi jumlah perkawinan tikus putih (Rattus norvegicus) secara kualitatif. Jurnal Farmasi Kalbar. 2015;3(1):4.

16. AVMA Guidelines for the euthanasia of animals: 2020 edition. Available from: https://www.avma.org/sites/default/files/202 0-01/2020-Euthanasia-Final-1-17-20.pdf

17. Artwohl J, Brown P, Corning B, Stein S; ACLAM Task Force.Report of the ACLAM Task Force on Rodent Euthanasia. J Am Assoc Lab Anim Sci. 2006;45(1):98-105.

18. The guide for the care and use of laboratory animals: $8^{\text {th }}$ edition. National Research Council 2011. Available from https://grants.nih.gov/grants/olaw/guide-forthe-care-and-use-of-laboratory-animals.pdf

19. Kurniawan C. Thomas BW, Perdamean S. Analisis ukuran partikel menggunakan free software image-J. Seminar Nasional Fisika, Pusat Penelitian Fisika-LIPI, Serpong 2011.

20. Saichudin. Mengoptimalkan stimulasi dan meminimalkan cedera sel purkinje cerebellum dalam menjaga dan meningkatkan kualitas gerak keolahragaan. Malang: The Learning Univesity; 2016. h. 87-8.

21. Nangoy BV, Kalangi SJR, Pasiak TF. Gambaran mikroskopik serebelum pada hewan coba postmortem. Jurnal Biomedik (JBM). 2019; 11(1).

22. Cassanueva E, Viteri FE. Iron and oxidative stress in pregnancy. J Nutr. 2003;133(1):1700S-8S.

23. Herndon RM. The fine structure of the purkinje cell. J Cell Biol. 1963;18(1):167-80.

24. Haschek W, Rousseaux C, Wallig M. Handbook of toxicologic pathology. San Diego: Academic Press; 2002. 
25. Kemp KC, Cook AJ, Redondo J, Kurian KM, Scolding NJ, Wilkins A. Purkinje cell injury, structural plasticity and fusion in patients with Friedreich's ataxia. Acta Neuropathol Commun. 2016;4(53). 